\title{
POSISI MADRASAH DALAM SISTEM PENDIDIKAN NASIONAL DI ERA OTONOMI DAERAH
}

\section{Daud Yahya*}

IAIN Antasari Jalan Ahmad Yani km. 4.5 Banjarmasin

e-mail:mdaudyahya@iain-antasariac.id

\begin{abstract}
Abstrack
Madrasah is an Islamic educational institutions that have a long history, and finally recognized part of the National Education System. Madrasas are already managed by Depag / Kemenag with the religious sector is a problem when faced with the UU regions autonomy which necessitates the education sector be transferred to the government. At the end of the progress the school is not located in the under Depag and Kemenag but on the creativity the school's own.
\end{abstract}

\begin{abstract}
Abstrak
Madrasah merupakan lembaga pendidikan Islam yang mempunyai sejarah perjalanan panjang, sampai akhirnya diakui bagian dari Sistem Pendidikan Nasional. Keberadaan madrasah yang sudah sangat lama di kelola oleh Depag/Kemenag melalui sektor agama menjadi problem tatkala dihadapkan dengan UU otonomi daerah yang meniscayakan sektor pendidikan diserahkan pengelolaannya pada Pemerintah Daerah. Pada akhirnya kemajuan madrasah bukan terletak pada berada di bawah Kemenag ataupun Kemendiknas tapi pada kreativitas madrasah itu sendiri.
\end{abstract}

Kata Kunci : Sistem Pendidikan Nasional, sektor agama, sektor pendidikan, otonomi daerah.

* Penulis adalah Dosen pada Fakultas Tarbiyah dan Keguruan IAIN Antasari Banjarmasin, alumnus Program S3 IAIN Sunan Apel tahun 2012 


\section{A. PENDAHULUAN}

Apabila kita simak sejarah lahirnya dan perkembangan madrasah dapat dikemukakan bahwa madrasah merupakan lembaga pendidikan yang lahir dari dan untuk masyarakat.Inilah identitas madrasah.Di dalam kaitan ini adalah sangat tepat apabila A. Malik Fadjar mengatakun bahwa, "Madrasah adalah madrasah."Artinya lembaga madrasah tidak dapat digantikan dengan lembaga-lembaga lainnya karena madrasah mempunyai visi, misi dan karakteristik yang sangat khas di dalam masyarakat dan bangsa Indonesia baik dilihat dari segi kebudayaan, pendidikan, politik, bahkan ekonomi. ${ }^{1}$ Embrio Madrasah telah mengalami perjalanan yang sangat panjang sejak masa Kesultanan, menjadi klasikal masa penjajahan, awal kemerdekaan sampai dengan sekarang.

Pemberlakuan UU No 22 Tahun 1999 tentang Otonomi Daerah berpengaruh terhadap sektor pendidikan, termasuk madrasah. Pemberlakuan otonomi daerah berpengaruh pada otonomi di sektor pendidikan. Madrasah mengalami kendala struktural berikut dampaknya bagi madrasah itu sendiri. Madrasah berada dalam situasi problematika. Pada satu sisi madrasah sudah diakui bagian dari Sistem Pendidikan Nasional. Pada sisi lain madrasah yang merupakan sektor agama, tidak diotonomikan. Sementara otonomi daerah menjadikan sektor pendidikan bagian dari yang diserahkan ke Pemerintah Daerah.

Tulisan ini akan membahas bagaimana posisi madrasah dalam Sistem Pendidikan Nasional dan kaitannya dengan posisi madrasah di era otonomi daerah.

\section{B. MADRASAH MASA PENJAJAHAN}

Pada masa kolonial sesuai dengan tnisi kolonialisme, pendidikan Islam dianaktirikan.pendidikan Islam dikategorisasikan sebagai sekolah liar. Bahkan pemerintah kolonial telah melahirkan peraturan-peraturan yang membatasi bahkan mematikan sekolah-sekolah partikuler termasuk madrasah dengan mengeluarkan peraturan yang terkenal "wilde schoolen ordonantie"tahun 1933. Akibat perlakuan negative dari pemerintah kolonial maka pendidikan

${ }^{1}$ A. R. Tilaar. Paradigma Baru Pendidikan Nasional (Jakarta : Rineka Cipta, 2000 h. 169 Sejarah pertumbuhan madrasah di Timur Tengah. bahwa madrasah merupakan bentuk formalisasi dari kelembagaan pendidikan Islam non formal seperti masjid, kuttab, maktab dansebagainya.Lihat Ahmad Syalabi, Tarikh al Tarbiyoh al Islamiyyah, (Mesir : Dar al Ma'arif. 1967), h. 87.Setidaknya ada empat madrasah yang muncul lebih awal dibanding dengan munculnya madrasah Nizhamiyah, yakni Madrasah Baihaqiyah.madrasah alSa'diyah, madrasahAbu Sa'ad al Astarubadi dan madrasah Abu Ishay al Isfarayani.. Lihat Abburahman Mas'ud, NizhamiyyaMadrasa as Model of Tradisional Education in the Mediecel Periode of Islam,(t.tp.,Media, 1998,h. 2. DiIndonesia madrasahhadir karena faktor Timur Tengah danfaktor penjajahanBelanda.Madrasah adalah salah satu lembaga pendidikan yang di Indonesia dikelola oleh Departemen Agama.Depertemen ini didirikan tanggal 3 Januari 1946.Ia merupakan kebijakan yang sudah direncanakansejak semula, Lihat Karel A. Stcnbrink, Pesantren Madrasah Sekolah, Pendidikan Islam Dalmn KurunModern, (Jakarta :LP3ES, 1986), h. 462. Konsep pcndidikan dapat diibaratkansebuah ;pakaian yang tidak dapat diimpor atau diekspor harus diciptakan sesuai dengan keinginan. ukurandan model dari orang yang memakainya, sehingga tampak pas dan serasi. Lihat Ali Khalil Abu, Ainain, al Fiker al tarbawiy ind ai Qur'an, (Mesir : Dar al Ma'arif: 1978), h. 98. Dalam situnsi peruhahan zaman, pendidikan Islam harus tampil membimbingmasyarakatsesuai semangat Al Qur'an dan sunah sesuai dengan perkembangan zaman. Lihat Mohd. Zaki Kirmani, The Qur'an and Future of Sience (India : Global Vision Publishing House, 2001), h.xii. 
Islam termasuk madrasah-madrasah menghadapi kesulitan-kesulitan yang terisolasi dari arus modernisasi².

Terlepas dari alasan itu, sangat boleh ,jadi penyebab utama diasingkannya sistem pendidikan Islam itu adalah karena kemungkinankonsekuensinya yang justru tidak menguntungkan kepentingun politik Hindia Belanda sendiri, Pendidikan Islam dalam prakteknya lebih menekankan kepada aspek keimanan dan keyakinan dalam beragama, yang secara langsung memberi rangsangan dan motivasi untuk melawan penjajahan dan pernerintahan yang kafir.

Pemberlakuan pendidikan pribumi oleh pemerintahan Hindia Belanda dapat dianggap sebagai awal dari dualisme sistem pendidikan bagi masyarakat Indonesia.Pendidikan Islam tetap berjalan sesuai dengan karakternya dan secara tradisional menjadi andalan masyarakai Indonesia, khususnya kaum Muslimin, sementara sistem pendidikan pribumi ala Belanda terus berkembang dan menjadi pusat pengajaran dan pelatihan bagi kaum elit pribumi yang memiliki hubungan dengan pemerintah Hindia Belanda. Dualisme pendidikan ini dalam perkembangannya menghasilkan orientasi dan wawasan rnasyarakat Indonesia yang terbelah sesuai dengan karakter masing-masing pendidikan yang ditempuhnya.Narnun, demikian, orientasi kaum terpelajar yang berlatar belakang pendidikan ala Belanda secara politis lebih siap menangani masalah-masalah kenegaraan, karena memang pola pendidikannya sejak awal mempersiapkan mereka untukmenjadi tenaga-tenaga pemerintahan.Hal ini membawa konsekuensi pada kecenderungan mereka untuk lebih mengembangkan pola dan orientasi pendidikan yang pernah dinikmatinya, ketika harus menentukan kebijakan dalam bidang pendidikan. ${ }^{3}$

Pada masakemerdekaan tidak dengan sendirinya pendidikan Islam dimasukkan didalam sistem pendidikan nasional.Organisasi pendidikan Islammemang terus hidup namun tidak rnemperoleh perhatian sepenuhnya dari pemerintah. Lembaga-lembaga pendidikan Islam dibiarkan hidup meskipun di dalam keadaan yang sangat sederhana dan hidup apa adanya. Nanti pada tahun 70 -an perhatian pernerintah mulai ditujukan kepada pembinaan madrasah misalnya dengan lahirnya SKB 3 Menteri tanggal 24 maret 1975.Pengakuan pendidikan Islarn dengan ciri khasnya baru dapat dilihat di dalam lahirnya UU No. 2 tahun 1989 tentang Sistem Pendidikan Nasional.Di dalam UU tersebut pendidikan madrasah diakui sebagai sub-sistem pendidikan nasional sebabaimana di dalam PP no. 28 Tahun 1990 tentang Pendidikan Dasar. Masuknya madrasah sebagai sub-sistem pendidikan nasional mempunyai berbagai konsekuensi antara lain dimulainya suatu pola pembinaan mengikuti satu ukuran yang mengacu kepada sekolah-sekolah pemerintah. ${ }^{4}$

\section{PERKEMBANGAN MADRASAH PASCA KEMERDEKAAN}

Pada dasarnya sejak masa awal kemerdekaan tidak ada masalah yang prinsipil mengenai pendidikan Islam dalam pengertian eksistensial.Keberadaannya di Indonesia

\footnotetext{
${ }^{2}$ A.R. Tilar, Paradigma Baru Pendidikan Nasional, (Jakarta : Rineka Cipta. 2000), h.170.

${ }^{3}$ Muhammad Yunus, Sejarah Pendidikan Islam Di Indonesia, (Jakarta : t.pn, 1980), h.90.

${ }^{4}$ A.R. Tilaar, Paradigma Baru Pendidikan Nasional, (Jakarta : Rineka Cipta, 2000), h.170.
} 
adalah suatu kenyataan yang sudah berlangsung sangat panjang dan sudah memasyarakat. Untuk kepentingan ini pun pada tahun 1946 dibentuklah Departemen Agama yang antara lain mengurusi pengajaran agama di sekolah negeri dan swasta, pengajaran umum di rnadrasah, dan penyelenggaraan Pendidikan Guru Agama (PGA) dan Pendidikan Hakim Islam Negeri (PHIN). Pembentukan Departemen Agama dengan beberapa tugasnya itu pun sebetulnya sudah didahului dengan pendirian lembaga serupa pada masa pemerintahan Jepang.

Berdasarkan rekornendasi itu tampak jelas bahwa lingkup pendidikan Islam berarti sangat terbatas pada pengajaran agama di sekolah-sekolah mulai kelas IV, dalam alokasi waktu seminggu sekali, dan tidak termasuk pelajaran Bahasa Arab. Mengenai pendidikan Islarn dalam pengertian khusus dalam rekomendasi itu kecuali kalimat nomor 9: "Kualitas pesantren dan madrasah harus diperbaiki." Mengenai batas materi pendidikan agama itu sendiri diisyaratkan oleh pernyataan Ki Hajar Dewantara, pimpinan Taman Siswa dan Menteri Pendidikandan Kebudayaan pertama yang "memandang pendidikan agama terutama hanya sebagai pendidikan budi pekerti, dan tidak setuju dengan pendidikan agama sebagai pengantar fiqh secara umum dalam agama islam.

Karena ketentuan-ketentuan dalam rekomendasi itu sifatnya masih umum maka dalam pelaksanaannya mengalami perkembangan yang berubah-ubah, agaknya tergantung pada tingkat hubungan antar kelompok kepentingan.Pada awalnya, ketentuan-ketentuan itu direalisasikan melalui Undang-undangPendidikan tahun 1950 No. 4 dan UndangUndang Pendidikan Tahun 1954 no.20, yang isinya agak kurang menguntungkan bagi pengembangan pendidikan Islam. UU itu antara lain menyebutkan dua hal:

1. Dalam sekolah-sekolah negeri diselenggarakan pelajaran agama; orangtua murid menetapkan apakah anaknya mengikuti pelajaran tersebut.

2. Cara menyelenggarakan pengajaran agama di sekolah-sekolah negeri diatur melalui ketetapan Menteri Pendidikan, Pengajaran dan Kebudayaan bersama-sama dengan Menteri Agama.

Seperti dapat dipahami dari namanya, Undang-undang No. 4 Tahun 1950 jo. No. 12 Tahun 1954 "Tentang Dasar-dasar Pendidikan dan Pengajaran di Sekolah" tersebut, terbatas pada pengaturan pendidikan di sekolah dan dalam kenyataannya tidak memberi perhatian yang cukup pada pendidikan di luar sekolah.Dalam pasal 2 UU tersebut bahkan ditegaskan bahwa "Undang-undang ini tidak berlaku untuk pendidikan dan pengajaran di sekolah-sekolah agama."Mengenal madrasah hanya diisyaratkan dalam pasal 10 ayat (2) bahwa belajar di sekolah agama yang telah mendapat pengakuan Menteri Agama dianggap telah memenuhi kewajiban belajar.

Sejak Indonesia merdeka, telah terjadi proses perkembangan madrasah kepada tiga fase: Pertama, madrasah pada periode pertama ini adalah dibatasi dengan pengertian yang tertulis pada peraturan Menteri Agama Nomor 1 Tahun 1746 dan peraturan Menteri Agama Nomor 7 tahun 1950, yaitu rnadrasah mengandung makna:

${ }^{5}$ Haidar Putra Daulay, Pendidikan Islam Dalam Sistem Pendidikan Nasional Di Indonesia, (Jakarta : Kencana, 2004), h.47. 
a. Tempat pendidikan yang diatur sebagai sekolah dan membuat pendidikan dan ilmu pengetahuan agama Islam menjadi pokok pengajarannya.

b. Pondok dan pesantren yang memberikan pendidikan setingkat dengan madrasah.

Konsentrasi utama madrasah pada fase ini adalah pengembangan ilmu--ilmu agama, karena itu ruang gerak madrasah lebih terbatas baik dari segi melanjutkan pelajaran maupun lapangan kerja. Tamatan madrasah seperti halnya berada dan menjadi keluarga besar Departemen Agama, baik untuk melanjutkan pelajaran maupun untuk lapangan pekerjaan. ${ }^{5}$

Namun menarik diamati, perhatian pemerintah yang begitu besar di awal kemerdekaan yang ditandai dengan tugas Departemen Agama dan beberapa keputusan BP KNIP tarnpaknya tidak berlanjut.Hal ini tampak ketika undang- undang pendidikan nasional pertama (UU No. 4 Tahun 1950) diundangkan, masalah madrasah dan pesantren tidak dimasukkan sama sekali, yang ada hanya masalah pendidikan agama di sekolah (umum). Dampaknya madrasah dan pesantren dianggap berada di luar sistenn. Oleh karena itu rnulai muncul sikap diskrimioatif pemerintah terhadap madrasah dan pesantren.

Pada tahap ini madrasah belum dipandang sebagai bagian dari sistem pendidikan nasional, tetapi merupakan lembaga pendidikan di bawah Menteri Agama.Hai ini disebabkan sistem pendidikan madrasah menurut pemerintah (Departemen P\&K) lebih didominasi "muatan-muatan agama, menggunakankurikulum yang belum berstandar, memiliki struktur yang tidak seragam, dan memberlakukan manajemen yang kurang dapat dikontrol oleh pemerintah. ${ }^{6}$

Masa UU No. 4 tahun 1950 jo. No. 12 tahun 1954, penghargaan tetap diberikan tercermin dengan ketentuan pasal bahwa belajar di madrasah yang diakui oleh Menteri Agama dianggap telah mengikuti wajib belajar.Juga munculnya PP tentang bantuan dan Subsidi untuk madrasah. ${ }^{7}$

Fase kedua masa orde baru. Secara umum diakui bahwa kebijakan pemerintah Orde Baru mengenai pendidikan agama, termasuk madrasah, bersifat positif dan konstruktif; khususnya dalam dua dekade terakhir 1908-an - 1990-an. Pemerintah Orde Baru memandang bahwa lembaga itu harus dikembangkan dalarn rangka pemerataan kesempatan dan peningkatan mutu pendidikan.Kebijakan seperti ini secara lebih kuat tercermin dalam komitmen Orde Baru untuk menyelenggarakan pendidikan agama sebagai bagian yang tidak terpisahkan dari Sistem Pendidikan Nasional.

Pada masa-masa awal pemerintahan OrdeBaru, kebijakan dalam beberapa hal mengenai madrasah bersifat melanjutkan dan memperkuat kebijakan Orde Lama. Pada tahap ini madrasah belum dipandang sebagai bagian dari sistem pendidikan secara nasional, tetapi merupakan lembaga pendidikan otonom di bawah pengawasan Menteri Agama.Hal ini disebabkan karena kenyataannya bahwa sietem pendidikan madrasah lebih didominasi oleh muatan-muatan agama, menggunakan kurikulum yang terstandar, memiliki struktur yang tidak seragam, dan memberlakukan manajemen yang kurang dapat dikontrol oleh

${ }^{6}$ Husni Rahim, Madrasah Dalam Politik Pendidikan Di Indonesia, (Jakarta : Logos, 2005), h.17.

${ }^{7}$ Husni Rahim, Madrasah Dalam Politik Pendidikan Di Indonesia, (Jakarta : Logos, 2005), h.90. 
pemerintah. Menghadapi kenyataan ini maka langkah pertama dalam pembaharuan pendidikan madrasah adalah rnelakukan formalisasi dan strukturisasi madrasah.Formalisasi ditempuh dengan menegerikan sejumlah madrasah dengan kriteria tertentu yang diatur oleh, pemerintah, di samping mendirikan nnadrasah-madrasah negeri yang baru. Sedangkan strukturisasi dilakukatt dengan mengatur penjenjangan danperumusan kurikulum yang cenderung sama dengan penjenjangan dan kurikulum sekolah-sekolah di bawah Departemen Pendidikan dan Kebudayaan. ${ }^{8}$

Perkembangan selanjutnya pada madrasah adalah Surat Keputusan Bersama (SKB) Tiga Menteri Tahun 1975.Pada fase ini terjadi perubahan orientasi madrasah dari lembaga yang konsentrasi keilmuannya dalam bidang agama, berubahmenjadi konsentrasinya pada pengetahuan umum.Batasan madrasah SKB Tiga Menteri adalah: "lembaga pendidikan yang menjadikan mata pelajaran agama Islam sebagai dasar yang diberikan sekurangkurangnya 30\% di samping mata pelajaran umum.

Dalam Surat Keputusan bersama Tiga Menteri Tahun 1975 dicantumkantujuan peningkatan adalah:

1. Ijazah madrasah dapat mempunyai nilai yang sama dengan ijazah sekolah umum setingkat.

2. Lulusan madrasah dapat melanjutkan ke sekolah umum setingkat lebih atas:

Siswa madrasah dapat berpindah ke sekolah umum yang setingkat. ${ }^{9}$ Lahirnya SKB 3 Menteri ini dianggap sebagai cikal bakal integrasinya madrasah dalam sistem pendidikan nasional.

\section{MENGINTEGRASIKAN MADRASAH DALAM SISTEM PENDIDIKAN NASIONAL}

Dengan disahkannya Undang-Undang.No.2 Tahun 1989 tentang Sistem Pendidikan Nasional, maka untuk pertama kalinya pendidikan Islam merupakan sub-sistem dari pendidikan nasional. Dalam perjalanan selanjutnya di era A. Malik Fadzar sebagai Mendiknas disahkan juga UU No. 20 Tahun 2003 tentang Sistem Pendidikan Nasional, yang semakin memperkuat kedudukan pendidikan Islam dalam sistem pendidikan nasional termasuk madrasah. Hal ini berarti pengolaan, mutu, kurikulum, pengadaan tenaga, dan lain-lain yang meliputi penyelenggaraan pendidikan nasional juga berlaku untuk pengembangan pendidikan Islam di Indonesia. Sudah tentu pengintegrasian pendidikan Islamsebagai sub-sistem pendidikan nasional menuntut berbagai penyesuaian di dalam arti yang positif.Dalam kaitan ini pendidikan Islam perlu mengkaji kembali hal-hal yang selama inibelum dibenahi sesuai dengan kemajuan zaman.Seperti kita ketahui berbicara

${ }^{8}$ M. Maksum, Madrasah Sejarah dan Perkembangannya, (Jakarta : Logos Wacana Ilmu, 1999), h.99.

${ }^{9}$ Haidar Putra Daulay, Pendidikan Islam Dalam Sistem Pendidikan Nasional Di Indonesia, (Jakarta : Kencana, 2004), h.48. 
mengenai sistem pendidikan Islam kita tidak berbicara mengenai satu jenis sistem tetapi berbagai jenis sistem. ${ }^{10}$

Akhir dekade 1980-an dunia pendidikan Islam memasuki era integrasi karena lahirnya UU No. 2/1989 tentang Sistem Pendidikan Nasional. Berbeda dengan Undang-Undang kependidikan sebelumnya, undang-undang ini mencakup ketentuan tentang semua jalur dan jenis pendidikan. Jika pada Undang-Undang sebelumnya pendidikan nasional bertumpu pada sekolah, maka dalam UUSPN ini pendidikan nasional mencakup jalur sekolah dan luar sekolah, serta meliputi jenis pendidikin akademik, pendidikan profesional, pendidikan kejuruan, pendidikankeagamaan. ${ }^{11}$ Meskipun secara eksplisit tidak mengatur secara khusus tentang pendidikan Islam, tetapi dalam prakteknya memberikan ketentuanketentuan baru mengenaijenis dari kurikulum pendidikan islam, khususnya pendidikan madrasah.

Posisi integrasi pendidikan Islam dalam Sistem Pendidikan Nasional tercermin dalam beberapa aspek. Pertama - merupakan aspek yang paling pentingpendidikan nasional menjadikan pendidikan agama sebagai salah satu muatan wajib dalam semuajalur dan jenis pendidikan. Kebijakan ini tentu sangat berartidalam proses integrasi pendidikan secara nasional karena telah meyakinkan khususnya kaum muslimin bahwa Sistem Pendidikan Nasional tidak bercorak sekuler. Salah satu keraguan kaum muslimin terhadap pendidikan nasional sebelum ini adalah karena status pendidikan agama yang kurang memuaskan, bahkan pernah diabaikan.Dengan ketentuan yuridis bahwa pendidikan agama merupakan muatan wajib dalam setiap, jalur dan jenjang pendidikan yang membuka wawasan positif di kalangan umat Islam bahwa anlara sekolah dan madrasah tidak memiliki perbedaan yang prinsip.

Kedua, dalam Sistem Pendidikan Nasional, madrasah dengan sendirinya dimasukkan ke dalam kategori pendidikan jalur sekolah.Jika sebelum ini terdapat dualisme antara

\footnotetext{
${ }^{10}$ Lihat ulasan-ulasan modernisasi pendidikan Islam oleh A. Maliki Fadjar, Visi Pernbaharuan Pedidikan Islam, (Jakarta : LPP\&PNI,1998), h.99. Keadaan ini bukan berarti merupakan kelamahan dari sistem pendidikan Islam tetapi justru merupakan kekuatan seperti yang akan dibicarakan pada bagian kedua tulisan ini. Masalahnya ialah dengan adanya satu system pendidikan nasional maka berbagai hal atau kegiatan perlu distandarisasikan dengan sistem yang telah disepakati sepanjang kegiatan tersebut mempunyai arti yang positif atau yang memberikan sumbangan bagi penyempurnaan system pendidikan nasional. Di dalam kajian ini perlu dikaji sejauh mana sub-sistem pendidikan Islam mempunyai nilai-nilai pendidikan yang tidak kalah pentingnya dan besar relevansinya di dalam pengembangan pendidikan nasional. Scbagai sub-sistem bukan bcrarti bahwa sub-sistem tersebut adalah interior terhadap sistem nasional. Di sini letak pentingnya pengembangan penelitian dan pengembanean di dalam sistem pendidikan Islam supaya dapat mengkaji hal-hal yang positif yang dapat disumbangkan kepada perbaikan system pendidikan nasional. Sebagai sub-sistem pendidikan nasional. visi pendidikan Islam tentunya sejalan dengan visi pendidikan nasional. Visi pendidikan nasional tidak lain ialah mewujudkan manusia Indonesia yang takwa dan produktif sebagai anggota masyarakat Indonesia yang takwa dan produktif sebagai anggota masyarakat Indonesia yang Bhineka. Dalam rumusanA.Syafi'i Maarif, yakni "Manusia yang unggul secara intelektual, kaya dalam amal serta anggun dalam moral dan kebijakan". Lihat Muslih Usa, Pendidikan Islam di Indonesia (Yogyakarta: Tiara Wacana,, 1991), h. 90.

${ }^{11}$ Undang — undang Sistem Pendidikan Nasional No.2 Tabun 1989,(Jakarta : Golden Terayon Press, 1994), h.99.
} 
sekolah dan madrasah, maka dengan kebijakan ini dapat dikatakan bahwa madrasah pada hakekatnya adalah Sekolah.Bahwa pengelolaan madrasah tetap di bawah Departemen Agama RI tidak berarti lembaga pendidikan itu mempertahankan eksklusifiitasnya, meskipun tetap bisa mempertahankan ciri-ciri keagamaannya.Dalam ukuran yang lebih jauh dan lebih kuat, ketentuan ini semakin mempertegas kedudukan madrasah yang sebelumnya telah diatur dalatri SKB Tiga Menteri. ${ }^{12}$

Dengan demikian, solusi tahun tujuh puluhan yang diambil untuk mengatasi ketegangan pendidikan, antara pendidikan agama dan pendidikan umum, akibat keluarnya Kepres No. 34 Tahun 1972 dan Inpres No. 15 Tahun 1974, yang kernudian melahirkan SKB Tiga Menteri, tampaknya telah dijadikan sumber inspirasi.Peristiwa dan langkah pada periode ini bisa dipandang sebagai momen strategis (strategicmoment) bagi eksistensi dan perkembangan madrasah pada masa berikutnya. Madrasah tidak saja tetap eksis dan dikelolah di bawahDepartemen Agama, tetapi sekaligus diposisikan secara mantap dan tegas seperti halnya sekolah dalam Sistem Pendidikan Nasional.

Pada tahap integrasi ini dapat dikatakan terjadi penerimaan madrasah ke dalarn sistem Pendidikan Nasional di satu pihak, dan transformasi madrasah ke dalam jalur pendidikan persekolahan di pihak lain. Dalam hal yang terakhir ini, secara umum madrasah mengalami perkembangan definisi yang tidak lagi rnerupakan lembaga pendidikan Islam dalam pengertian eksklusif keagamaan, tetapi sudah merupakan lernbaga pendidikunjalur sekolah yang berakar pada budaya bangsa Indonesia. ${ }^{13}$ Semua bentuk kegiatan pendidikan di Indonesia tercakup dalam Sistem Pendidikan Nasional, termasuk pendidikan di madrasah dan pondok pesantren yang diselenggarakan atau dibina oleh Departemen Agama dan selama ini lebih dikenal sebagai lembaga perguruan agama Islam. ${ }^{14}$ Perkembangan ini agaknya belum pernah terjadi di masa sebelumnya karena berbagai kendala baik yang menyangkut intern ummat Islam ataupun karena kondisi politik pernerintah di kala itu.

Prestasi legitimasi madrasah dalarn UUSPN 1989 yang merupakan perjuangan panjang sejak awal Orde Baru, sejatinya dimulai ketika Departemen Agama melakukan formalisasi strukturisasi kelembagaan madrasah sebagai akibat pelaksanaan pendidikan nasional yang masih bertumpu pada UU No. 4/1950 jo. No.12/1945 tentang Dasardasar Pendidikan dan Pengajaran di Sekolah.

${ }^{12}$ Pasal 49 dan Pasal 50 UUSPN, Himpunan Peraturan Perundang-undangan Sistem Pendidikan Nasional, (Jakarta: Departemen Agama RI, 1994/1995), h. 19. Integrasi madrasah ke dalam Sistem Pendidikan Nasional dengan demikian bukan merupakan integrasi dalam artian penyelenggaraan dan pengelolaan pendidikan, termasuk madrasah oleh Departemen Pendidikan, dan Kebudayaan, tetapi lebih pada pengakuan yang lebih mantap bahwa madrasah adalah bagian dari system pendidikan nasional walaupun pengelolaannya dilimpahkan pada Departemen Agama. Dengan tetap mengacu pada dasar, tujuan, dan kurikulum pendidikan sebagaimana diatur dalam Undang-Undang sncara nasional, Departemen Agama meniiliki kewenangan untuk mempola model dan proses pendidikan pada semua jenis dansatuan pendidikan keagamaan, termasuk madrasah, secara kreatif.

${ }^{13}$ Zamakhsyari Dhofier. "The Intellectualization of Islamic Studies in Indonesia" dalam Islamic Culture 58 (Juni 1992), h. 19-31.

${ }^{14}$ A. Malik Fadzar, Madrasah dan Tantangan Modernitas, (Bandung : Mizan, 1999), h.66. 
Sementara itu, pembaharuan yang dilakukan terhadap institusi madrasah belum optimal: (1) Sistem pendidikan madrasah lebih didominasi oleh muatan-muatan agama; (2) Kurikulum yang ada belum terstandar; (3) Memiliki struktur yang tidak seragam; dan (4) Manajemen yang kurang baik.

Dalam konteks ini, pengakuan madrasah masuk ke wilayah sistem pendidikan formal sudah diusahakan dalam UU No. 2/1989 tentang Sistem Pendidikan Nasional, meskipun secara eksplisit tidak disebutkan. Pasal 11 ayat 1 misalnya, hanya menyebutkan: "Jenis pendidikan yang termasuk jalur pendidikan sekolah terdiri atas pendidikan umum, pendidikan kejuruan, pendidikan kedinasan, pendidikan keagamaan, pendidikan akademik, dan pendidikan profesional.

Meskipun demikian, UU tersebut telah berimplikasi dalam pemberian ketentuanketentuan baru mengenai jenis dan kurikulum pendidikan Islam, khususnya pendidikan madrasah, Misalnya, keputusan Menteri Agama No. 368/93 dan 369/93 tanggal 22 Desember 1993 dan No. 054/U/1993 tentang kesetaraan antara lelnbaga pendidikan berciri khas Islam (MI, MTs, dan MA) dengan lembaga pendidikan umum (SD, SLTP dan SMU). Juga Keputusan Menteri Agama No.8/22/1993 tentang Kurikulum Pendidikan berciri khas Islam yang mengakomodasi muatan pelajaran yang ada di Kurikulum Pendidikan Umum.Legitimasi lembaga pendidikan Islam, khasusnya madrasah dan pesantren mencapai puncaknya ketika RUU Sisdiknas yang secara eksplisit mengatur penyelenggaraan kedua pendidikan tersebut disahkan oleh DPR pada pertengahan Juni $2003 . .^{15}$

${ }^{15}$ Suhadi, Pemberdayaan Pendidikan Masyarakat, (Jakarta : LA. 2003), h. 42. Fase madrasah setelah Undang-undang No. 2 tahun 1989, madrasah pada periode ini disebut sebagai sekolah yang berciri khas Islam. Pengertian bahwa seluruh programnya sama dengan sekolah yang ditambah dengan mata pelajaran agama Islam sebagai ciri keislamannya. Pada tingkat menengah disebut Madrasah Aliyah sama dengan sekolah yang berciri khas agama. Setelah diberlakukannya Undang-Undang Sistem Pendidikan Nasional (UU No. 2 Tahun 1989) dari diiringi dengan sejumlah Peraturan Pemerintah (PP) No. 28 dan 29 dan diteruskan dengan berlakunya UU No. 20 Tahun 2003. Madrasah pada fase ini bahwa madrasah mulai dari tingkat dasar dan menengah memberlakukan kurikulum sekolah yang ditambah dengan kurikulum ilmu-ilmu agama sebagai ciri khasnya. Implikasi penting UUSPN terhadap pendidikan madrasah dapat diamati pada kurikulum dan semua jenjang madrasah, mulai dari Ibtidaiyah, Tsanawiyah hingga Aliyah. Secara umum penjenjangan itu paralel dengan Penjenjangan pada pendidikan sekolah, mulai SD, SMP hingga SMA. Kurikulum madrasah juga sama dengan sekolah dengan pengecualion naa;a pelajaran agama yang lebih banyak.Madrasah bukan lagi sebagai lembaga eksklusif pendidikan keagamaan. Lihat. Haidar Putra Daulay, Pendidikan Islam Sistem Pendidikan Nasional di Indonesia, (Jakarta: Kencana, 2004), h. 9-17.

Secara operasional, integrasi madrasah ke dalam sistem pendidikan nasional ini dikuatkan dengan PP No. 28 tahun 1990 dan SK Mendikbud No. 0487/U/1992 dan No. 054/1993 yang antara lain menetapkan bahwa MI/MTs wajib memberikan bahan kajian sekurang-kurangnya sama dengan SD/SMP, SK-SK ini ditindak lanjuti dengan SK Menteri Agama No. 368 dan 369 tentang penyelenggaraan MI dan MTs. Sementara tentang Madrasah Aliyah (MA) diperkuat dengan PP Nomor 29 tahun 1990. SK Mendikbud Nomor 0489/U/1992 (MA sebagai SMU berciri khas keagama Islam) dar.SK Menag Nomor 370 tahun 1993.Pengakuan ini mengakibatkan tidak ada perbedaan lagi antara .MI/MTs/MA dan SD/SMP/SMA selain ciri khas agama lslamnya.lntegrasi madrasah ke dalam sistem pendidikan nasional dengan demikian hukan merupakan integrasi dalam arti penyelenggaraan dan pengelolaan madrasah oleh Departemen Pendidikan Kebudayaan (Sekarang Depdiknas). tetapi lebih pada pengakuan yang lebih mantap bahwa 
Dalam perkembangan selanjutnya setelah UU No 20Tahun 2003 yang telah disahkan Presiden pada tanggal 8 Juli 2003 setelah melalui perdebatan yang panjang di masyarakat dan Dewan Perwakilan Rakyat. Dalam Undang-undang ini diakui kehadiran pendidikan di samping pendidikan umum, kejuruan, akademik, profesi, vokasi dan keterampilan khusus (pasal 15).Dalam UU ini MI, MTs, MA dan MA Kejuruan sudah dimasukkan dalam jenis pendidikan umum dan pendidikan kejuruan. Hal ini untuk memperkuat pendidikan Islam dari menghindari dari kendala struktural ${ }^{16}$

Ada perkembangan yang menggembirakan bagi pesantren dan diniyah dalam UU No. 2 Tahun 2003. Bahwa kenyataannya, UU Sisdiknas No. 2/1989 pada Bab IV tentang Satuan, Jalur, dan Jenis Pendidikan tidak menyebut samasekali kata "pesantren" sebagai bagian dari jalur maupun jenis pendidikan.

Tetapi ada satu kemajuan berarti bagi prospek sistem pendidikan pesantren dalam UU Sisdiknas yang telah diamandemen mengakomodasi sistem pendidikan pesantren sebagai bagian integral sistem pendidikan nasional. Dalam UU Sisdiknas pada Bagian ketujuh tentang Pendidikan Keagamaan Pasal 30 ayat 4 disebutkan: "Pendidikan keagamaan berbentuk pendidikan diniyah, Pesantren pasraman, pahbajasamanera, dan bentuk lain yang sejenis ${ }^{17}$

Dalam UU No. 2 tahun 2003 lebih dipertegas lagi tentang kedudukan madrasah pada pasal 17 ayat (2) dijelaskan pcndidikan dasar bcrbentuk SckolahDasar (SD) dan Madrasah Ibtidaiyah '(MI) atau bentuk lain yang sederajat serta Sekolah Menengah Pertama (SNIP) dan Madrasah Tsanawiyah (MTs), atau bentuk lain yang sederajat. Sedangkan pada pasal (18) ayat (3) menjelaskan pendidikan menengah berbentuk Sekolah Menengah Atas (SMA), Madrasah Aliyah (MA), Sekolah Menengah kejuruan (SMK) dan Madrasah Aliyah Kejuruan (MAK) atau bentuk lain yang sederajat. ${ }^{18}$

madrasah adalah bagian dari sistem pendidikan nasional walaupun pengelolaannya dilimpahkan pada departemen Agama. lihat Haidar. Undang-Undang No.2 Tahun 1989 tentang pendidikan nasional telah mengakui keberadaan madrasah sebagai bagian dari sistem pendidikan nasional dan berdasarkan PP No. 28 dan 29 Tahun 1989 ditetapkan bahwa madrasah adalah sekolah umum yang berciri khas Islam dan kurikulum madrasah adalah sama dengan kurikulum sekolah plus ciri khasnya. Ciri khas madrasah secara formal dinyatakan dalam kurikulum dalam bentuk mata pelajaran agama.Di mana kurikulum agama pada madrasah lebih banyak dibandingkan dengan pelajaran agama di sekolah. Pada tingkat SD pelajaran agama 2 jam, maka pada MI menjadi 4 s/d 7 jamdan pada MTs dan MA menjadi 9jam. Oleh karena itu dalam memberikan ciri khas Islam pada rnadrasah, muka dilakukan pula upaya mcmberikan "nuansa Islam" pada bidang studi umum (MAFIKIL3B).Bidang studi MAFIKIBB berdasar kurikulum 94 sangat sukar bagi kebanyakan guru madrasah dan pondok pesantren untuk mengajarkanya dan sulit hagi siswa untuk memahaminya. Guru mudrasah / pesantren tidak dipersiapkan untuk rnelaksanakan kurikulum 94. Demikian pula para siswanya tidak terbiasa dengan pendidikan yang bukan agama.Ciri khas lainnya, memberikan "nuansa Iptek" pada bidang studi agama. Artinya memberikan tafsiran kontekstual kekinian (Iptek) dalam pelajaran agama Lihat Husni Rahim, Madrasah Dalam Polilik. Pendidikan Di Indonesia,

(Jakarta: Logos, 2005), h. 47. Lihat pula Haidar Putra Daulay, Pendidikan Islam Dalam Sistem Pendidikan Nasionaldi Indonesia, (Jakarta: Kencana, 2004), h.18.

${ }^{16}$ Husni Rahim, Madrasah Dalam Politik Pendidikan Di Indonesia, (Jakarta : Logos, 2005), h.24.

${ }^{17}$ Suhadi, Pemberdayaan Pendidikan Masyarakat, (Jakarta : LA. 2003), h.69.

${ }^{18}$ Haidar Putra Daulay, Pendidikan Islam Dalam Sistem Pendidikan Nasional Di Indonesia (Jakarta : Kencana, 2004), h.47. 


\section{E. NUANSA-NUANSA PENDIDIKAN ISLAM DALAM SISTEM PENDIDIKAN NASIONAL BERDASAR UU NO.2 TAHUN 2003}

Ada beberapa pasal dalam UU No. 20 Tahun 2003 yang menyinggung tentang pendidikan Islam.Di dalam aturan tersebut setidaknya ada tiga hal yang terkait dengan pendidikan Islam.Pertama, kelembagaan formal, nonformaldan informal didukungnya lembaga madrasah sebagai salah satu lembaga pendidikan formal yang diakui keberadaannya setara dengan lembaga pendidikan sekolah, selanjutnya diakui majelis taklim sebagai pendidikan nonformal dan dimasukan Rasudhatul Athfal sebagai lembaga pendidikan anak usia dini, dan dipertegas pula tentang pesantren sebagai lembaga pendidikan keagamaan. Kedua, pendidikan Islam sebagai mata pelajaran dikokohkannya mata pelajaran agama sebagai salah satu mata pelajaran yang wajib diberikan kepada peserta didik di semua jalur, jenis dan jenjang pendidikan.Ketiga, pendidikan Islam sebagai nilai, terdapat seperangkat nilai-nilai Islami dalam sistem pendidikan nasional.

1. Pendidikan Islam sebagai lembaga

a. Lembaga pendidikan formal

1) Pendidikan Dasar (pasal 17) menyebutkan:

Pendidikan Dasar berbentuk Sekolah Dasar (SD) dan Madrasah Ibtidaiyah (MI) atau bentuk lain yang sederajat serta Sekolah Menengah Pertama (SMP) dan Madrasah Tsanawiyah (MTs) atau bentuk lain yang sederajat.

2) Pendidikan Menengah (Pasal 18):

Pendidikan Menengah berbentuk SekolahMenengah Atas (SMA), Madrasah Aliyah (MA), Sekolah Menengah Kejuruan (SMK),dan Madrasah Aliyah Kejuruan (MAK) atau bentuk lain yang sederajat.

3) Pendidikan Tinggi (Pasal 20)

Pendidikan Tinggi dapat berbentuk Akademi, Politeknik, Sekolah Tinggi, Institut, atau Universitas.

b. Lembaga Pendidikan Nonformal (Pasal 26)

Satuan pendidikan nonformal terdiri atas lembagakursus, lembaga pelatihan, kelompok belajar, pusat kegiatan masyarakat, dan majelis taklim, sertasatuan pendidikan sejenis.

c. Lembaga Pendidikan Informal (Pasal 27)

Kegiatan pendidikan informal yang dilakukan keluarga dan lingkungan kegiatan belajar secara mandiri.

d. Pendidikan Usia Dini (Pasal 28)

Pendidikan usia dini pada jalur pendidikan formal berbentuk Taman Kanak-kanak (TK), Raudhatul Athfial (RA), atau bentuk lain yang sederajat.

e. Pendidikan Keagamaan (Pasal 30)

1) Pendidikan keagamaan diselenggarakan oleh pemerintah atau kelompok masyarakat dari pemeluk agama, sesuai dengan peraturan perundang-undangan. 
2) Perdidikan keagamaan berfungsi mempersiapkan peserta didik menjadi anggota masyarakat yang memahami dan mengamalkan nilai-nilai agamanya dan atau menjadi ahli agama.

3) Pendidikan keagamaan dapat diselenggarakan pada jalur pendidikan formal, nonformal dan informal.

4) Pendidikan keagamaan berbentuk pendidikan diniyah, pesantren, pasraman, pabhaya samena; dan bentuk lain yang sejenis.

2. Pendidikan Agama Sebagai Kurikulum

Kurikulum pendidikan dasar dan menengah wajib memuat Pendidikan agama. Begitupun Kurikulum pendidikan tinggi wajib memuat Pendidikan agama

3. Nilai-nilai Islam Dalam UU No.2U Tahun 2003

Inti dari hakikat nilai-nilai Islam itu adalah nilai yang membawa kemaslahatan dan kesejahteraan bagiseluruh mahluk (sesuai dengan konseprahmatan lil'alamin), demokratis, egalitarian dan humanis. Di antara nilai--nilai tersebut adalah:

1) Pendidikan nasional adalah pendidikan yangberdasarkan Pancasila dan Undangundang dasar Negara Republik Indonesia Tahun 1945 yang berakar pada nilai-nilai agama, kebudayaan nasional Indonesia dantanggap terhadap tuntutan perubahan zaman.

2) Tujuan pendidikan Islam sesuai dengan tujuan pendidikan nasional. Pendidikan nasional berfungsi mengembangkan kemampuan dan membentuk watak serta peradaban bangsa yang bermartabat dalam rangka berkembangnya potensi peserta didik agar menjadi manusia yang beriman dan bertaqwa kepada Tuhan Yang Maha ESA, berakhlak mtllia, sehat, berilmu, cakap, kreatif, mandiri, dan menjadi warga yang demokratis serta bertanggungjawab.

3) Pendidikan nasional bersifat demokratis dan berkeadilan serta tidak diskriminatif.

4) Memberikan perhatian kepada peserta didik yang memiliki kelainan fisik, emosional, mental, sosial dan atau memiliki potensi kecerdasan dan bakat istimewa.

5) Menekankan pentingnya pendidikan keluarga merupakan salah satu upaya mencerdaskan kehidupan bangsa melalui pendidikan seumur hidup.

6) Pendidikan merupakan kewajiban bersama antara orangtua, masyarakat dan pemerintah $^{19}$

\section{F. MADRASAH DI ERA OTONOMI DAERAH}

Harus kita akui bahwa madrasah mempunyai nilai-nilai positif di samping tentunya berbagai kelemahan yang perlu dibenahi. Salah satu kelemahan madrasah karena perkembangan historisnya serta perkembangan juridis dari lembaga-lembaga tersebut

\footnotetext{
${ }^{19}$ Lihat Undang Undang Sistem Pendidikan NasionalNo.20/2003, Jakarta : Dirjen Dikdasmen, BPPHBTAN, 2003), h. 1-110. Lihat juga Haidar Putra Daulay, Pendidikan Islam Sistem Dalam Sistem Pendidikan Nasional Di Indonesia, (Jakarta ; Kencana, 2004), h.9-10.
} 
telah menghasilkan mutu yang masih rendah serta manajemennya yang masih perlu dibenahi, sarana yang kurang memadai, penggajian guru yang apa adanya.Namun banyak nilai yang merupakan jiwa madrasah yang sungguh sesuai dengan cita-cita reformasi. Di dalam usaha kita untuk membangun suatu masyarakat demokratis serta mengikutsertakan masyarakat secara optimal di dalam penyelenggaraan dan pengaturan kehidupan bermasyarakat, maka lembaga pendidikan madrasah merupakan contoh hidup yang perlu diaktualisasikan. ${ }^{20}$

\section{Otonomi Daerah: UU No.20 Tahun 1999/UU No.32 Tahun 2004}

Menurut BN. Marbun, bahwa otonomi daerah tidak sekedar pendelegasian atau devolusi kewenangan pemerintah pusat kepada pemerintah daerah untuk mengatur dan mengurus rumah tangganya sendiri, tetapi secara langsung dan tidak langsung mendistribusikan gerak pembangunan dan tanggung jawab ke seluruh penjuru daerah. Daerah-daerah harus dipercaya dan tidak dicurigai, bahwa masa depan mereka adalah tanggungjawab mereka juga. Otonomi daerah mendorong kemandirian daerah secara harmonis danberlomba-lomba secara luas (fair) dengan daerah lainnya. Pemerintah pusat cukup memberi arah dan menjaga kestabilan politik dan ekonomi nasional.Apa yang sudah dapat dan bakal dapat dikerjakan daerah sendiri, maka mereka harus didorong merealisasikannya. ${ }^{21}$

Selain itu tak dapat dibantah bahwa pembangunan yang dilancarkan oleh pemerintah Orde Baru selama ini telah banyak membawa hasil bagi rakyat. Tetapi proses pembangunan itu agaknya tidak berjalan secara merata bagi semua kelompok masyarakat. Akibatnya timbul kesenjangan sosial yang cukup tajam antara lapisan yang memperoleh pendapatan melimpah dengan massa rakyat yang belum dapat memenuhi kebutulian fisik mereka yang paling minim sekalipun. Sejalan dengan Undang-undang pelaksanaan Undang-undang Otonomi Daerahsebagaimana tersebut di atas, kini ada empat tantangan yang menonjol.Pertama, dukungan untuk membangkitkan institusi lokal yang berbasis masyarakat.Undang-undang Nomor 22 Tahun 1999 membolehkan daerah pedesaan untuk berlandaskan pada adat-istiadat dan asal-usul masing-masing daerah.Ini adalah bagian dari kesinambungan atas kebangkitan lembaga adat dan struktur pemerintahan tradisional.Kebangkitan adat Nagari di Sumatera Barat (menggantikan desa) merupakan salah satu kasus terkenal mengenai kebangkitan adat.

Kedua, membangun kepemimpinan baru.Pada masa lalu, seperti tertulis di atas, kepala desa adalah penguasa tunggal di komunitasnya, yang.tidak boleh dilawan. Hal ini menuju kepada penyalahgunaan kekuasaan dan korupsi, karena tidak adanya pemeriksaan dan perimbangan yang demokratis.

Ketiga, menempatkan pedesaan secara kokoh sebagai bagian integral dari perkembangan politik nasional. Lebih dari $60 \%$ penduduk Indonesia tinggal di daerah

${ }^{20}$ A.R. Tilaar, Paradigma Baru Pendidikan Nasional, (Jakarta : Rineka Cipta, 2000), h.174.

${ }^{21}$ B.N. Marbun, Otonomi Daerah 1945-2005 Proses dan Realita Perkembangan Otda, Sejak. Zaman Kolonial Sampai Saat Ini, (Jakarta : Sinar Harapan, 2005), h.ix. 
pedesaan, akan tetapi akhir-akhir ini tidak ada politisasi atau tokoh nasional yang berbicara atas nama desa. Jarak sosial dan geografis antara desa ke kabupaten dan apalagi dari desa ke Jakarta sangat jauh.Walaupun desentralisasi meajanjikan untuk memudahkan pengambilan keputusan lebih dekat dengan masyarakat, serta membuat pemerintah lebih dapat bertindak langsung, hal ini harus dibuktikan dalam praktek.Bisa saja, pemerintah lokal yang otoriter akan dapat lebih menindas dari pada rekannya di pusat, karena mereka mempunyai akses langsung kepada tingkat paling rendah.

Keempat adalah apakah perlu penekanan pada otonomi atau demokrasi? Hal ini dikemukakan, karena sebagaimana telah diuraikan di atas,bahwa banyaknya penekanan pada otonomi desa, dengan struktur internal yang hirarkis, mungkin akan berakibat desadesa tersebut menjadi kurang demokratis. ${ }^{22}$

Berdasarkan uraian tersebut; dapat diketahui bahwa hakikat otonomidaerah adalah pemberian wewenang yang lebih luas kepada daerah untukmembangun dengan kekuatan dirinya sendiri secara maksimal dan optimal.Dengan cara demikian, keadaan di desa akan lebih meningkat kehidupannya dalam segala bidang, sebagai suatu keadaan yang berbeda dengan keadaan pada masa-masa yang lalu. Dengan kata lain, Otonomi Daerah selain merupakan peluang juga sekaligus tantangan, yakni apakah mereka mampu mengatasi tantangan-tantangan tersebut dan merubahnya menjadi peluang. Keterbatasan anggaran, sumber daya manusia yang unggul, sarana dan prasarana, manajemen dan tekanan dari politik pemerintah pusat sering kali menjadi faktor yang menyebabkan daerah belum dapat memanfaatkan tantangan-tantangan tersebut menjadi peluang. Permasalahan ini pada gilirannya mengharuskan adanya sumber daya manusia yang unggul untuk mengatasi tantangan Otonomi Daerah tersebut, yaitu sumber daya manusia yang sehat jasmani dari rohaninya, memiliki wawasan dan pengetahuan yang luas, memiliki keterampilan mempergunakan teknologi yang canggih, memiliki etos kerja yang tinggi, berkepribadian utama dan berakhlak mulia. Guna menghasilkan manusia-manusia yang demikian itu pada gilirannya mengharuskan dunia pendidikan mengambil langkah-lungkah konkrit, strategis dan berkesinambungan.

Selanjutnya dalam Undang-undang Republik Indonesia Nomor 32 Tahun 2004tentang Pemerintah Daerah dinyatakan bahwa dalam rangka penyelenggaraan pemerintah daerah sesuai dengan amanat Undang-undang Dasar Negara Republik Indonesia Tahun 1945, pemerintah daerah, yang mengatur dan mengurus sendiri urusan pemerintahan menurut asas otonomi dan tugas, pembantuan, diarahkan untuk mempercepatterwujudnya kesejahteraan masyarakat, melalui peningkatan pelayanan, pemberdayaan dan peran serta masyarakat, serta peningkatan daya saing daerah dengan memperhatikan prinsip demokrasi, pemerataan, keadilan, keistimewaan dan kekhususan suatu daerah dalam sistem Negara Kesatuan Republik Indonesia. ${ }^{23}$

\footnotetext{
${ }^{22}$ Timpal P. Saragi, Mewrjudkan Otonomi Masyarakat Desa, (Jakarta : YA, 2004), h.xv.

${ }^{23}$ Tim Penyusun,UU No.23 Tabun 2004 Tentang Pemerintahan dan UU No.22 Tabun 2004 Tentang Perimbangan Keuangan Antar Pemerintah Pusat dengan Pemerintah Daerah, (Surabaya : Serta Jaya. 2005), h.1.
} 
Selanjutnya dalam Bab III Pasal 10 Undang-undang No. 32 Tahun 2004 tentang Pemerintah Daerah dinyatakan bahwa (1) Pemerintah Daerah menyelenggarakan urusanpemerintahan yang rnenjadi kewenangannya, kecuali urusan yang pemerintahan yang oleh Undang-undang ini ditentukan tnenjadi urusan pemerintah. (2) Dalam menyelenggarakan urusan pemerintahan yang menjadi kewenangan daerah sebagaimana dimaksud pada ayat (1) pemerintah daerah menjalankan otonomi seluas-luasnya untuk mengatur dan mengurus sendiri urusan pemerintahan berdasarkan asas otonomi dan tugas pembangunan; (3) Urusan pemerintah yang menjadi urusan Pemerintah Pusat sebagaimana dimaksud pada ayat (1) meliputi: (a) polisi luar negeri; (b) pertahanan; (c) keamanan; (d) yustisi; moneter danfiskalnasional; dan (f) agama. (4) Dalam menyelenggarakan urusan pemerintah sebagaimana dimaksud pada ayat (3), Pemerintah menyelenggarakan sendiri atau dapat melimpahkan sebagian urusan pemerintahan kepada perangkat pemerintah atau wakil Pemerintah di daerah atau dapat menugaskan kepada pemerintah daerah dan/atau pemerintah desa, dan (5) Dalam urusan pemerintahan yang menjadi kewenangan pemerintah di luar urusan sebagaimana dimaksud pada ayat (3), pemerintah dapat: (a) menyelenggarakan sendiri sebagian urusan pemerintahan; (b) melimpahkan sebagian urusan pemerintahan kepada Gubernur selaku wakil pemerintah; atau (c) menugaskan sebagian urusan kepada pemerintahan daerah dan/atau pemerintahan desa berdasarkan asas tugas pembantuan. ${ }^{24}$

Kutipan tersebut di atas memperlihatkan dengan jelas, bahwa lahirnya Undangundang yang berkenaandengan pemerintahan daerah tersebut dilatarbelakangi oleh gagasan dan pemikiran yang amat ideal. Undang-undang tersebut mengandung scmangat tentang perlunya pemerataan pelaksanaan demokrasi secara nyata di masyarakat, pemerataan pendapatan, pemerataan peluang untuk maju dan bersaing secara sehat, penyiapan diri untuk menghadapi tantangan global yang makin kompetitif, pemerataan kesejahteraan masyarakat, serta pendewasaan masyarakat, dengan tetap berada dalam kerangka Negara Kesatuan Republik Indonesia.

Gagasan dan pemikiran ideal sebagaimana tersebut di atas merupakan cita-cita dan sekaligus tuntutan masyarakat yang terjadi di era reformasi. Masyarakat melihat bahwa berbagai peraturan perundang-undangan yang menyangkut otonomi daerah yang ada sejak zaman penjajahan Belanda hingga zaman pemerintahan Orde Baru dianggap tidak berjalan, dan telah menimbulkan berbagai keadaan yang kurang sejahtera, terutama di daerah-daerah.Berbagai analisa dan kajian tentang sebab-sebab mengapa undang-undang tentang otonomi daerah tersebut tidak berjalan telah banyak dilakukan pada ahli.

Kebanyakan desa di Indonesia saat ini sudah mempunyai sekolah, listrik dan Puskesmas.Akan tetapi harga campur tangan negara dan pembangunan ekonomi tersebut mungkin terlalu tinggi untuk dapat dibayar. Beberapa hal yang berkaitan dengan masalahmasalah tersebut adalah, antara lain keseragaman dan standarisasi, penghancuran susunan sosial, pernilihan pemimpin-pemimpin masyarakat, kekurangpercayaan terhadap

\footnotetext{
${ }^{24}$ Tim Penyusun, UU No.23 Tabun 2004 Tentang Pemerintahan dan UU No.22 Tabun 2004 Tentang Perimbangan Keuangan Antar Pemerintah Pusat dengan Pemerintah Daerah, (Surabaya : Serta Jaya. 2005), h.12.
} 
pemerintah, kerukunan sosial juga dihancurkan oleh Orde Baru yang menimbulkan kemiskinan dan marginalisasi. ${ }^{25}$

Melalui Undang-Undang No. 2 Tahun 1999/UU No. 32 Tahun 2004,kepengurusan, pendidikan dan kebudayaan diserahkan kepada daerah bahkan kepada kabupaten.Hal ini mempunyai implikasi yang sangat jauh di dalam pengelolaan pendidikan yang lebih dekat kepada kebutuhan masyarakat dandaerah. Pendidikan Islam yang telah dilaksanakan melalui pondok-pondok pesantren dan madrasah adalah sebenarnya merupakan pelaksanaan otonomi pendidikan. Oleh sebab itu sudah tiba masa bagi kita untuk lebih mengembangkan dan menyempurnakan pengalaman-pengalaman pengelolaan otonomi pendidikan sebagaimana yang telah dilaksanakan di pondak-pondok pesantren dan madrasah.Kajian mengenai pengalaman-pengalayan tersebut bukan hanya bermanfaat bagi pengembangan pendidikan Islam tetapi juga bagi pengembangan pendidikan nasional yang lebih merakyat.

Dengan uraian di atas, makin jelas kepada kita betapa relevansinya pengalaman pengelolaan pendidikan Islam di dalam menghadapi perubahan-perubahan besar di dalam masyarakat dengan demokratisasi pendidikan nasional. Proses demokratisasi ini yang merupakan salah satu unsur penting di dalam reformasi total kehidupan berbangsa dan bernegara kita, ternyata sudah kita mulai secara lebih mendasar di dalam sistem pendidikan kita khususnya di dalam pendidikan Islam yang telah mempunyai pengalaman dalam pelaksanaannya. Di dalam kaitan ini pendidikan Islam merupakan ujung tombak dari usaha reformasi pengelolaan pendidikan nasional yaitu mengembalikan kepedulian masyarakat tcrhadap pendidikannya. ${ }^{26}$

Madrasah adalah lembaga pendidikan yang dikelola departemen agama sejak awal kehadiran departemen ini. Namun dengan telah disahkannya UU NO. 22 Tahun 1999 tentang pemerintahan Daerah, dan UU NO.25 Tahun 1999 tentang Pertimbangan Keuangan antar perintah pusat dan daerah, muncul dilema mengenai status madrasah. Ketentuan UU No.22 Tahun 19997 ayat (1) menyatakan bahwa kewenangan daerah mencakup kewenangan dalam seluruh bidang pemerintah, kecuali kewenangan dalam bidang politik luar negeri, pertahanun keamanan, peradilan, moneter dan ,fiskal agama serta kewenangan bidang lain).

Di lain pihak pasal 11 ayat (2) menyatakan bahwa pendidikan dan kebudayaan salah satu dari 11 (sebelas)bidang yang wajib dilaksanakan daerahkabupaten dan daerah kota. Pertanyaan lanjutan yang muncul dari penafsiran terhadap dua pasal di atas adalah apakah termasuk dalam bidang pendidikan ataukah bidang agama? Di sini muncul dua pendapat:

Pertama, yang mengatakan bahwa pendidikan agama dan pendidikan lain yang diasuh Departemen Agama tidak diotonomikan sebagaimana maksud pasal 7 ayat satu dari UU No. 22 Tahun 1999.Ini berarti pendidikan di Departemen Agama dikategorikan sebagai bagian dari sistem agama, bukan bagian dari sistempendidikan nasional,

\footnotetext{
${ }^{25}$ Timpal P. Saragi, Mewnjudkan Otonomi Masyarakat Desa, (Jakarta : YA, 2004), h.x.

${ }^{26}$ A.R Tilaar, Pandangan baru Pendidikan Nasional, (Jakarta : Rineka Cipta, 2000), h.158.
} 
Kedua, yang mengatakan bahwa pendidikan agama dan pendidikan yang dikelola Departemen Agarna adalah bagian dari sistem pendidikan nasional.Karena pendidikan diotonomikan, maka pendidikan di lingkungan Departemen Agama juga harus diotonomikan. Hal ini sejalan dan dimungkinkan oleh penjelasan dari pasal 7 ayat 1 yaitu: “...khusus di bidang keagamaan sebagian kaitannya dapat ditegaskan oleh pemerintah kepada Daerah sebagai upaya meningkatkan keikutsertaan daerah sebagai upaya menumbuhkembangkan kehidupan beragama."Ini bermakna tidak diotonomikan "agama" masih memberi peluang penugasan bidang-bidang tertentu dalam agama kepada Daerah. ${ }^{27}$

Departemen Agama merupakan salah satu departemen yang dipercayakan oleh undang-undang untuk mengelola pendidikan mulai dari tingkat prasekolah sampai perguruantinggi.Dengan diberlakukannya UU No.22 Tahun1999 tentang Otonomi Daerah, Menteri Agama telah mengirim surat kepada Menteri Dalam Negeri dan Otonomi Daerah, dengan surat No. 402 tanggal 21 November 2000 yang isinya adalah menyerahkan pengelolaan pendidikan agama di sekolah umum dan penyelenggaraan Madrasah Ibtidaiyah, Tsanawiyah dan Aliyah ke pihak Departemen Dalam Negeri dan Otonomi daerah. Penyerahan itu meliputi operasional penyelenggaraan, penjabaran kurikulum, penyediaan tenaga pendidikan, penyediaan sarana dan prasarana, penyediaan anggaran. ${ }^{28}$ Namun seiring zaman, kebijakan bisa berubah.

Ada beberapa alternatif pilihan bagi madrasah di era otonomi daerah. Pertama, kalaulah sentralisasi yang menjadi pilihan, maka Departemen Agama masih secara langsung menyelenggarakan pembinaan dan pengendalian madrasah-madrasah di seluruh tanah Air sebagaimana selama ini dijalankannya.Pilihan ini mengandung makna bahwa Departemen Agama memandang madrasah berada dalam kategori bidang agama. Sumber dana yang diberikan untuk melakukan pembinaan dapat secara langsung dikelola oleh Departemen Agama. Sementara daerah menjadi pelaksana dari kebijakan pusat seperti selama ini berjalan.Bahkan, pemerintah pusatdalam hal ini Departemen Agamaberhak menentukan jenis-jenis program dan target yang semestinya dicapai oleh masing-masing madrasah di berbagai tingkatannya. ${ }^{29}$

${ }^{27}$ Husni Rahim, Madrasab Dalam Politik Pendidikan Di Indonesia, (Jakarta : Logos, 2005), h.2-3.

${ }^{28}$ Haidar Putra Daulay, Pendidikan Islam Dalam Sistem Pendidikan Nasional Di Indonesia, (Jakarta : Kencana, 2004), h.46.

${ }^{29}$ Husni Rahim, Madrasah Dalam Polilik Pendidikan Di Indonesia, (Jakarta: Logos, 2005), h.4. Sekilas kelihatannya pilihan ini sangat menguntungkan Nantun, bila dikaji lebihjauh, ternyata pilihan ini hisa menjadi boomerang bagi Departemen Aagma maupun madrasah- madrasah yang berada di bawah binaannya. Ada lima alasan untuk menjelaskannya :

Pertama, sesuai dengan Bab IV Pasal 7 UU No. 22/1999 yang memberikan sentralisasi pada lima bidang di atas. maka dapat dipastikan bahwa sumberdana pembinaan madrasah berasal dari bidang pendidikan yang pursinya sudah banyak didaerahkan.

Kedua, boleh jadi madrasah tidak menjadi bagian dari sistem pendidikan nasional, tetapi menjadi bagian dari sistem agama.Sedangkan Undang-undang di atas justru menyerahkan pengelolaan pendidikan sepenuhnya kepada pemerintah daerah tingkat II. Konsekuensinya, madrasahtidak akan pernah mendapatkan perhatian dan perlakuan yang sama dari pemerintah daerah di mana madrasah itu berada. 
Kedua, jika disentralisasi yang menjadi pilihan, maka kita menyerahkan pembinaan madrasah ke tangan pemerintah daerah tingkat II. Itu berarti, Departemen Agama (pusat) akan kehilangan sasaran binaan kelembagaan pendidikan. Dengan demikian,peran bepartemen Agama menjadi mengecil sebatas urusan bidang agama semacam haji, zakat, infaq, sadaqah, nikah, talak, rujuk, masjid, tempat ibadah lainnya dan huhungan antar umat beragama.beberapa binaan juga beberapa tenaga profesional hasil binaan DepartemenAgama terpaksa hengkang ke Departemen Pendidikan Nasional. ${ }^{30}$

Pertanyaan lain yang timbul, jika pendidikan di lingkungan Departernen Agama tidak ditugaskan kepada daerah, bukan tidak mungkin daerah merasa kurang bertanggung jawab terhadap madrasah dan menganggap madrasah adalah tugas dari pemerintah pusat (Departemen Agama). Bila muncul perasaan dan sikap seperti antara sekolah dan madrasah di daerah. Ini berbahaya dan dapat menimbulkan kesenjangan kembali antara madrasah dan sekolah yang telah dialami begitu, panjang (sejak UU No. 4 Tahun 1950 s/d UU No. 2 Tahun 1989).

Memang ada kekhawatiran sebagian pihak, bahwa kalau madrasah diserahkan kepada daerah timbul kekhawatiran jangan jangan ciri khas madrasah tidak dapat dipertahankan sehingga madrasah tidak ada bedanya dengan sekolah. Bukankah pengelola pendidikan di Diknas itu bukan orang-orang yang berlatar belakang pendidikan madrasah, sehingga

Ketiga, bolehjadi budaya akademik yang dikembangkan oleh guru dan kepala madrasah akan terganagu oleh keputusan politik dari pusat tersebut.

Keempat, masyarakat menjadi tidak peduli terhadap kondisi keuangan madrasah, malah semakin menggantungkan harapan soal pendanaan kepada pemerintah pusat.

Kelima, birokrasi tetap tidak efisien, berbelit-belil sehingga ada persoalan dari bawah tidak segera teratasi, malah berpanjang-panjang kata sehingga masalah menumpuk dan tidak terselesaikan. Husni Rahim, Madrasah Dalam Politik Pendidikan Pendidikan Di Indonesia,(Jakarta : Logos, 2005), h.5.

${ }^{30}$ Husni Rahim, Madrasah Dalam Politik Pendidikan Di Indonesia, (Jakarta: Logos, 2005), h.6. Ada sekitar lima keuntungan manakala alternatif kedua ini menjadi pilihan.

Pertama,madrasah akan segera "dikukuhkan" dan "diakui" menjadi bagian dari sistem pendidikan nasional. Dengan pengukuhan dan pengakuan tersebut, madrasah akan memperoleh perlakuan sejajar tidak lagi diskriminatif dengan sekolah umum, demikian juga hal pendanaan maupun status sosial.

Kedua, para guru dan kepala madrasah menjadi lebih leluasa mengembangkan sumber daya maupun dana yang dimiliki seraya belajar merumuskan program kerja yang lebih realistis dan relevan benban kebutuhan masyarakat.

Ketiga, iklim akademik dapat tumbuh dan berkembang secara alami seiring dengan kebebasan madrasah mengekspresikan diri dalam bentuk program kerja serta pengelolaan sumber daya maupun dana yang tersedia.

Keempat, madrasah melalui guru dan kepala madrasah dapat memanfaatkan secara muksimal elemenelemen masyarakat untuk kepentingan peningkatan kualitas sarana dan prasarana pendidikan di lingkungan madrasah itu sendiri.

Kelima, fokus pembinaan yang selama ini lebih menekankan pada persoalan administralif dapat dikurangi. Sambil berusaha menumbuhkembangkan kreatifilas di bidang akademikagar kekuatan administrasi mampu terimbangi dengan baik oleh kekuatan akademik. jika tidak, kita pandai- menciptakan "manusia pekerja". tetapi tidak pandai melahirkan "manusia pemikir". Mestinya pilihan yang satu tidaklah menegaskan pilihan yang lain. Kita ingin kedua kekuatan itu ada pada kita secara baikdan menjadi penguat lembaga yang kita miliki. Husni Rahim, Madrasah Dalam Politik Pendidikan Di Indonesia, (Jakarta : Logos, 2005), h.8. 
mereka tidak dapat memahaini "ruh" dari madrasah, sehingga dikhawatirkan kebijakankebijakan yang diambil akan menghilangkan ciri khas dari madrasah itu sendiri.

Ketiga, mungkin dengan membentuk forum pengkajian otonomi madrasah. Bolehjadi ide untuk "bedol desa" pendidikan di Departemen Agama ke Departemen Pendidikan Nasional dan ke Pemerintah Daerah suatu hal yang dapat menjadi bahan diskusi. Dengan"bedol desa" tersebut kekhawatiran bahwa di Diknas dan di Pemda tidak mempunyai SDM yang mengenal "ruh" madrasah dan kurang berpihak kepada madrasah dapat dihindari. Dengan demikian kekhawatiran ciri khas madrasah akan hilang atau pudar menjadi tidak beralasan. Bedol desa dengan arti seluruh perangkat dan personal pengelola pendidikan di Departemen Agama pindah (boyong) ke Diknas termasuk perangkat di daerah pindah ke Pemerintah Daerah. Dengan demikian maka madrasah tidak akan terisolir atau diisolir oleh sistem tapi menjadi bagian yang kokoh dari sistem dan perlakuan diskriminatif ataupun dianak tirikan tidak akan muncul.

Demikian pula kekhawatiran kekurangan guru bidang studi umum yang diberikan Diknas sedikit, serta anggaran pendidikan untuk Departemen Agama belum professional, tidak akan muncul. Perlakuan diskriminatif dalam pemberian dana bantuan bagi guru sekolah dengan guru madrasah akan dapat dihindari, sehingga perasaan sesama guru menjadi semakin kokoh antara sesama pendidik. Banyak lagi barangkali keuntungan yang didapatkan madrasah, yang terang perlakuan terhadap madrasah akan sama dengan sekolah, kekhawatiran bisa tetap ada, karena itu ketika proses bedol desa perlu diisyaratkan adanya jaminan bahwa madrasah akan mendapat perlakuan yang seimbang dengan sekolah-sekolah yang kini berada dalam naungan Depdiknas. ${ }^{31}$

Keempat, memang ada juga pemikiran yang akomodatif yang menginginkan pendidikan madrasah tetap di bawah departernen agama secara struktural, namun pengelola pada tingkat daerah diotonomikan sejalan dengan diberlakukannya undang-undang tersebut.Sebab, otonomi pendidikan di madrasah dimaksudkan sebagai desentralisasi pengelolaan madrasah, pengelolaan pendidikan berdasarkan kebutuhan madrasah maupun masyarakat. Di sini, madrasah akan diberikan kewenangan penuh dalam merancang kebutuhan masyarakat, misalnya, kepala sekolah bersama guru, orang tua, murid, bahkan masyarakat, berwenang membuat keputusan bersama tentang penyelenggaraan pendidikan yang dibutuhkan. ${ }^{32}$

${ }^{31}$ Husni Rahim, Madrasah Dalam Politik Pendidikan di Indonesia, (Jakarta: Logos, 2005), h.2-9.

${ }^{32}$ Husni Rahim, Madrasah Dalam Politik Pendidikan Di Indonesia, (Jakarta: Logos, 2005), h.8. Kebijakan inisepertinya merupakan "kompromi" namun tetap perlu dikritisi, karena memang dapat memecahkan persoalan di tingkat Daerah, namun belum memecahkan persoalan di tingkat pusat antar Departemen Agama dan Departemen Pendidikan Nasional. Pada tingkat pusat masih banyak persoalan yang dapat memunculkan diskriminasi lagi seperti persoalan pembagian alokasi dana. Bukankah alokasi dana pendidikan di tentukan oleh Departemen Pendidikan bersama DPR(komisi Xdan komisi Anggaran)? Sedangkan departemen Agama bermitra dengan komisi VIII.Demikianjuga struktur pendanaan pada sektor pendidikan yang terbagi atas pendidikan dasar dan menengah, pendidikan tinggi, pendidikan luar sekolah dan peningkatan mutu merupakan cerminan Ditjen di Diknas?Lalu di mana untuk Madrasah dan keagamaan? Tentu akan memerlukan perjuangan yang keras dan teliti untuk tidak "tertinggal atau di tinggal". Inilah berbagai 
Kelima, melakukanjoin management atau sharing kewenangan antara diknas dan depag.Misalnya melakukan Mou seperti yang dilakukan Kaltim, Jatim.

Keenam, melakukan revisi terhadap UU No. 32 Tahun 2004 tentang Pemerintah Daerah bahwa Agama (khususnya pendidikan) juga diotonomikan. Dalam hal ini madrasah (termasuk pesantren, diniyah) berada di Depag tapi mendapat dana APBD karena diotonomikan.

Ketujuh, mencontoh pola masuknya Pengadilan Agama ke Mahkamah Agung.

Kedelapan, madrasah sebagai bagian dari pendidikan Dasar dan Menengah diserahkan ke pemda/diknas. Sebagai kompensasi depag melepas madrasah maka dana yang dipakai untuk madrasah selama ini dipakai untuk jenis pendidikankeagamaan seperti pesantren, diniyah (termasuk PTAI).

\section{G. PEMBERDAYAAN MADRASAH DI ERA OTONOMI DAERAH}

Di dalam kaitan manajemen madrasah dengan ikutsertanya Departemen Agama, Departemen Pendidikan Nasional, Departemen Dalam Negeri, dan Pemerintah Daerah dalam rangka otonomi daerah, bagaimanapun bentuk penyelenggaraannya, yang harus dipertahankan ialah terjaminnya identitas madrasah. Identitas madrasah dengan ciri khasnya hanya dapat terjamin dengan adanya pengakuan otonomi lembaga.Otonomi lembaga pendidikan madrasah hanya dapat dipertahankan apabila madrasah tetap mempertahankan basisnya sebagai pendidikan yang berbasiskan masyarakat (communitybased education) yang selanjutnya menuju kepada otonomi madrasah sebagai lembaga (school-basedmanagement). ${ }^{33}$ Pendidikan yang masih berbasis birokrasi harus sudah diganti dengan sistem pendidikan yang berorientasipada kebutuhan masyarakat. ${ }^{34} \mathrm{Apa}$ pun perubahan-perubahan yang ingin disongsong, kebijakan-kebijakan mengembangkan madrasah perlu mengakomodasikan tiga kepentingan: Kepentingan pertama adalah bagaimana kebijakan itu pada dasarnya harus memberi ruang tumbuh wajar bagi aspirasi umat Islam. Yakni, menjadikan madrasah sebagai wahana untuk membina ruh atau praktek hidup keislaman. Kepentingan kedua adalah bagaimana kebijakan itu memperjelas dan memperkukuh keberadaan madrasah sebagai ajang membina warga negara yang cerdas, berpengetahuan, berkepribadian, serta, produktif, sederajat dengan sistem sekolah. Kepentinganketiga adalah bagaimana kebijakan itu bisa menjadikan madrasah dapat merespons tuntutan-tuntutan masa depan. Untuk itu madrasah perlu diarahkan kepada lembaga yang sanggup melahirkan sumber daya manusia yang memiliki kesiapan memasuki era globalisasi, era industrialisasi, ataupun era informasi. ${ }^{35}$

kemungkinan yang perlu didiskusikan lebih lanjut dengan semangat "tidak merugikan madrasah dan pendidikan keagamaan" itu sendiri. Husni Rahim,Madrasab Dalam Politik Pendidikan Di Indonesia, Jakarta: Logos, 2005), h.11.

${ }^{33}$ A.R. Tilaar, Paradigma Baru Pendidikan Nasional, (Jakarta : Rineka Cipta, 2000), h.179.

${ }^{34}$ Suwito, "Pendidikan Yang Memberdayakan",Pidato Pengukuban Guru Besar Sejarah Pemikiran dan Pendidikan Islam, IAIN Syarif Hidayatullah Jakarta, 2002.

${ }^{35}$ A. Malik Fadzar, Madrasah dan Tantangan Modernitas, (Bandung : Mizan, 1999), h.31-32. 
Di era otonomi daerah, arah baru paradigma pendidikan mengalami perubahan. Dan sentralisasi ke desentralisasi, kebijakan yang top down ke arah kebijakan bottom up. Orientasi pengembangan parsial pendidikan ke orientasi pengembangan holistik, pendidikan untuk pengembangan kesadaran untuk bersatu dalam kemajemukan budaya.Peranan pemerintah sangat dominan untuk meningkatkan peran masyarakat secara kualitatif dan kuantitatif.Lemahnya peran institusi nonsekolah ke pemberdayaan institusi masyarakat, keluarga, LSM, pesantren, dan dunia usaha. ${ }^{36}$

Integrasi madrasah ke dalam sistem pendidikan nasional beserta otonominya mengharuskan adanya paradigma baru penyelenggaraan madrasah.Tidak ada lagi diskriminasi terhadap sistem madrasah dalam hal pembiayaan, peningkatan SDM, dan peningkatan mutu pendidikan. Di sisi lain, madrasah dituntut memberdayakan dirinya untuk mampu setara dengan lembaga pendidikan umum, dengan tetap membawa kultur dan karakteristiknya sebagai lembaga yang lahir dari masyarakat bawah (grassroot)

Maka di era otonomi pendidikan ini, ada beberapa hal yang harus dilakukan madrasah.Pertama, mengakomodasikan berbagai masukan dan kritik dari stakeholders, sekaligus memberikan kepercayaan kepada mereka untuk berpartisipasi aktif dalam penyelenggaraan pendidikan madrasah.

Kedua, madrasah hendaknya menjadi lembaga inklusif dan universal yang mampu keluar dari jebakan-jebakan dikotomis yang selama ini melingkupi keilmuan dilembaga pendidikan ini.Madrasah hendaknya menerima integrasi ilmu-ilmu umum dengan terbuka, serta memberikan kebebasan kepada para siswa untuk mendalami pengetahuan/keilmuan sesuai pilihan atau minatnya.

Ketiga, madrasah harus menjadi lembaga yang responsif terhadap berbagai perubahan dan kebutuhan masyarakatnya, khususnya yang terjadi dalam dunia kerja. Artinya, bagaimana madrasah mampu menjadi lembaga link and match yang menyediakan lulusan yang siap kerja dengan berbekal nilai-nilai keagamaan. Tentu untuk ini, dibutuhkan waktu, sarana dan prasarana yang tidak sedikit. Oleh karena itu, paradigma efektif dan efesiensi dalam proses pendidikan harus dikedepankan.

Otonomi pendidikan memberikan kemandirian terhadap lembaga pendidikan madrasah menuju kemandirian dan keberdayaannya dalam bingkai keislaman dan kemasyarakatan.Tetapi, semua itu mesti menuntut tanggung jawab dari diri sendiri bersama seluruh masyarakat. Karena, tidak sepantasnyalah kita selalu menyalahkan birokrasi atau pemerintah sebagai penghambat kemajuan, madrasah. ${ }^{37}$

Bertolak dari arah baru ini maka pemberdayaan madrasah dilaksanakan lewat:

1. Pemberdayaan manajemen, meliputi pemberdayaan SDM, manusia pengelola pendidikan, kepala sekolah, guru, tenaga administrasi, pengawas, dan lain sebagainya dan siap memasuki era manajemen berbasis sekolah.

${ }^{36}$ Fasli Jalal dan Dedi Supriadi, , Reformasi Pendidikan dalam Konteks Otonomi Daerah, (Yogyakarta : Adicipta Karya Nusa, 1999), 98.

${ }^{37}$ Suhadi, Pemberdayaan Pendidikan Masyrakat, (Jakarta : LA. 2003), h.42-43. 
2. Pemberdayaan sistemnya, dan sistem top down ke bottom up, sentralisasi ke desentralisasi.

3. Pemberdayaan kebijakan, dan kebijakan yang memarjinalkan madrasah kepada kebijakan yang membawa madrasah ke center.

4. Pemberdayaan masyarakat, melibatkan unsur-unsur masyarakat untuk ikut serta dalam pemberdayaan madrasah, dengan cara meningkatkan peran serta stakeholderdan akuntabilitas. ${ }^{38}$ Diakui faktor "ideologi" (motivasi keagamaan) dan dakwah merupakan satu hal yang mendorong madrasah dengan segala keterbatasannya baik gaji, sarana, $\mathrm{dsb}$, namun masih bisa bertahan. Untuk itu madrasah harus mempunyaipengembangan reformulasi baru sebagai pemain inti dalam skop yang luas, inklusif, tidak sempit, universal didalam sistem pendidikan nasional kita. Oleh karena pengembangan madrasah harus selalu dilakukan terus menerus.

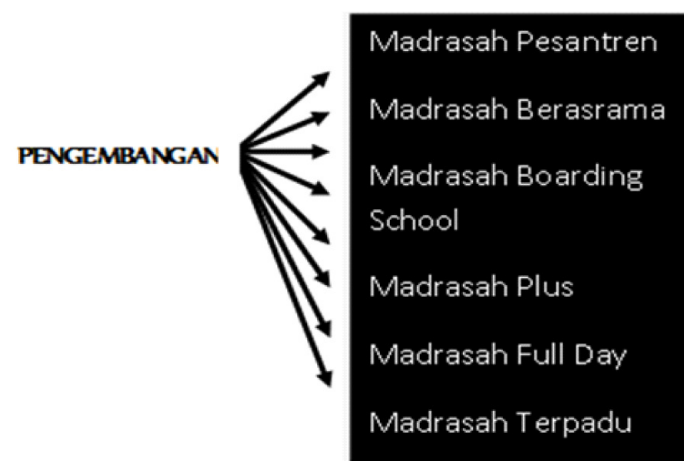

\section{H. PENUTUP}

Posisi madrasah dalam sistem pendidikan nasional adalah kuat karena dianggap sebagai pendidikan jalur sekolah dan diakui sejajar dengan sekolah umum.Madrasah adalah bagian dari Pendidikan Dasar dan Menengah dan bernilai plus ciri khas Agama Islam.Madrasah merupakan salah satu pola reintegrasi keilmuan Islam.Saat ini madrasah diakui sebagai bagian dari sistem pendidikan nasional namun pengelolaannya berada dibawah pembinaan Departemen Agama. Di era otonomi daerah madrasah mengalami kendala dalam pengakuan Pemerintah Daerah terhadap madrasah yang merupakan bagian dari sektor agama secara pembinaan (dimana agama tidak diotonomikan) dan bagian dari sektor pendidikan secara sistem pendidikan nasional (sementara pendidikan diotonomikan), sehingga madrasah yang termasuk bagian agama tidak dimasukkan dalam anggaran APBD dan APBN dari sektor pendidikan, serta guru madrasah hanya mendapat kesejahteraan rakyat/ tunjangan daerah yang relatif kecil.Oleh karena itu madrasah mengalami kendala struktural.Dari berbagai telaahdan inspirasi pemikiran ada beberapa alternatif pemecahan. Sebenarnya dalam UU No.32 Tahun 2004 Tentang Pemerintah Daerah pasal 10 ayat 3 disebutkan bahwa Pemerintah/sektor agama dapat melimpahkan atau menugaskan sebagian kewenangannya misal bidang pendidikan kepada pemerintah

${ }^{38}$ Haidar Putra Daulay, Pendidikan Islam Dalam Sistem Pendidikan Nasional Di Indonesia, (Jakarta : Kencana, 2004), h.62. 
daerah. Diharapkan peran madrasah tidak hanya budan lil muttaqintapi budan lin nasdalam menghadapi perubahan zaman yang begitu cepat berubah, apalagi tujuan pendidikan nasional dalam UU Sisdiknas No.20 Tahun 2003 sangat sejalan dengan tujuan pendidikan IsIam.

Pemberdayaan madrasah merupakan hal sangat penting di era otonomi daerah, era otonomi pendidikan. Sudah ada beberapa madrasah yang sudah masuk kategori madrasah unggulan seperti madrasah Pembangunan UIN Syarif Hidyatullah Jakarta, MIN Malang, MAN Insan Cendekia dan lain-lain, yang ternyata bisa mengalahkan sekolah yang ada dibawah naungan Kemendiknas. Ini menunjukkan aspek manajemen suatu lembaga pendidikan termasuk madrasah akan sangat menentukan keberhasilan suatu lembaga pendidikan. Uang hanya sebagai salah satu faktor dan bukan satu-satunya faktor.Selain itu perlu kesabaran secara bertahap dalam rangka penyamaan derajat, penyamaan perlakuan dengan sekolah Kemendiknas, karena bagaimanapun madrasah dengan sejarah panjangnya sudah dianggap bagian dari sistem pendidikan nasional. Pada akhirnya kemajuan madrasah bukan terletak pada apakah berada di Kemenag ataupunberada di Kemendiknas tapi terletak pada kreativitas madrasah itu sendiri dalam berbenah diri.Secara umum meski madrasah dalam pencapaian aspek kognitif semisal nilai UAN ${ }^{39}$ bisa lebih rendah dari sekolah dibawah naungan Kemendiknas, tapi pada aspek pengembangan mental, karakter, spiritual, madrasah lebih tinggi dari sekolah dibawah naungan Kemendiknas.

\section{DAFTAR PUSTAKA}

Abul Ainain, Ali Khalil. al Fiker al Tarbawiy ind al Qur'an. (Mesir : Dar al Ma'arif, 1978).

B.N. Marbun. Otonomi Daerah 194S-2005 Proses dan Realita Perkembangan Otda, Sejak Zaman Kolonial Sampai Saat Ini.(Jakarta: Sinar Harapan, 2005).

Dhofier, Zamakhsyari, “The Intellectualization ofIslamic Studies in Indonesia," dalam Islamic Culture 58 (Juni 1992).

Fadjar, A. Malik.Visi Pembaharuan Pendidikan Islam.(Jakarta : LPP \& PNI,1998). -Madrasah dan Tantangan Modernitas. (Bandung : Mizan, 1999).

Himpunan Peraturan Perundang-undangan Sistem Pendidikan Nasional. (Jakarta: Departemen Agama RI, 1994/1995).

Jalal, Fasli, dan Dedi Supriadi. Reformasi Pendidikan Dalam Konteks Otonomi Daerah.(Yogyakarta : Adicipta Karya Nusa, 2001).

Kirmani, Mohd. Zaki.The Qur'an and Future of Sience. (India: Global Vision Publishing Fluose, 2001).

Maksum, M.Madrasab;Sejarah dan Perkembangannya.(Jakarta: Logos Wacana HIM, 1999).

Mas'ud, Abdurrahman. Niøhamiyya Madrasaas Model of Tradisional Education in the Medieval Period of Islam.(t.tp. : Media, 1998).

\footnotetext{
${ }^{39}$ Sementara salah satu kritik terhadap pendidikan di Indonesia adalah lebih fokus pada pengembangan aspek kognitif.
} 
Putra Daulay, Haidar. Pendidikan Islam Dalam Sistem Pendidikan Nasional Di Indonesia.(Jakarta : Kencana, 2004).

Rahim, Husni. Madrasah Dalam Politik Pendidikan Di Indonesia.(Jakarta: Logos, 2005).

Stenbrink, Karel. Pesantren, Madrasah, Sekolah, Pendidikan Islam Dalam Kurun Modern. (Jakarta : LP3ES, 1986).

Suhadi.Pemberdayaan Pendidikan Masyarakat. (Jakarta : LA, 2003).

Suwito."Pendidikan Yang Memberdayakan". Pidato Pengukuhan Guru Besar Sejarah Pemikiran dan Pendidikan Islam. IAINSyarif HidayatullahJakarta,2002.

Syalabi, Ahmad. Tarikh al Tarbiyah al lslamiyyah. (Mesir :Dar al Ma'arif, 1967).

Tadjab. Pendidikan Islam Dalam Sistem Pendidikan Nasional. (Yogyakarta : t.pn. 1990).

Tilaar, A.R. Paradigma Baru Pendidikan Nasional. (Jakarta : Rineka Cipta,2000).

Timpal P. Saragi. Mewnjudkan Otonomi Masyarakat Desa.(Jakarta: YA, 2004).

Undang-undang Sistem Pendidikan Nasional No 2 Tabun 1989.(Jakarta: Golden Terayon Press, 1994).

Undang-undang Sistem Pendidikan Nasional NO. 20 Tabun 2003. (Jakarta: Dirjen Dikdasmen BPPHBTAN, 2003).

Usa,Muslih. Pendidikan Islam di Indonesia.(Yogyakarta : Tiara Wacana, 1991).

UU No. 32 Tabun 2004 tentang Pemerintahan Daerab dan UU No. 33 Tabun 2004 Tabun 2004 tentang Perimbangan Keuangan antara Pemerintah Pusat dan Pemerintah Daerah (Surabaya: Serta Jaya, 2005).

Himpunan Peraturan Perundang-undangan Sistem Pendidikan Nasional, (Jakarta: Departemen Agama R1, 1994/1995).

Yunus, Mahmud. Sejarah Pendidikan Islam Di Indonesia.(Jakarta : t.pn, 1980). 